\title{
Efektywna demokracja parlamentarna Michela Debré
}

Francja lat 30. stanowiła laboratorium słabości demokracji parlamentarnej. III Republika, będąca dotychczas wzorem dla wielu państw europejskich, weszła w fazę głębokiego kryzysu połączonego ze wzrostem popularności tendencji autorytarnych. Bez wątpienia nieefektywność francuskiego modelu demokracji parlamentarnej należała do przyczyn upadku republikańskiej Francji w 1940 r. Jedną z najciekawszych analiz i zarazem prób przezwyciężenia słabości demokracji parlamentarnej znajdziemy w pracach Michela Debré, napisanych w okresie II wojny światowej. Wypracowany przez niego projekt zracjonalizowanego parlamentaryzmu zasługuje na szczególne zainteresowanie, także dlatego, że inspirował tworzenie V Republiki.

Tytułem wstępu należy powiedzieć, że Michel Debré był ściśle związany z tradycją republikańską. Przyszedł na świat w 1912 r. w mieszczańskiej rodzinie pochodzenia żydowskiego, całkowicie wrośniętej w społeczeństwo francuskie. Po anektowaniu Alzacji przez Niemcy w 1870 r. jego rodzina odrzuciła możliwość egzystencji pod panowaniem niemieckim i przeprowadziła się do Paryża. Młody Debré robił błyskotliwą karierę prawniczą i bardzo szybko wszedł w świat prestiżowych instytucji publicznych. Po ukończeniu École des Sciences Politiques (Szkoła Nauk Politycznych w Paryżu) i uzyskaniu doktoratu z prawa objął stanowisko audytora w Radzie Stanu. W 1940 r., po ucieczce z niewoli niemieckiej, Debré przedostał się do wolnej strefy i wznowił pracę w Radzie Stanu, która przeniosła się do Royat. W 1942 r. nawiązał kontakt z Résistance, w lutym 1943 r. stał się członkiem ruchu Ceux de la Résistance (CDLR), a dwa miesiące później wszedł w skład Comité General d’Études (CGE), założonego przez Jeana Moulina w celu programowania polityki powojennej. Był bardzo aktywny w CGE - wywarł zasadniczy wpływ chociażby na opracowanie projektu reform ustrojowych. 
W 1944 r. Michel Debré był komisarzem Republiki, a w kwietniu 1945 r. wszedł do gabinetu Charles'a de Gaulle'a, w którym odpowiadał za przygotowanie reform administracyjnych. $Z$ jego inicjatywy i według pomysłu, który przedstawił jeszcze przed wojną, została powołana Państwowa Szkoła Administracji ${ }^{1}$. Po dymisji de Gaulle'a w 1946 r. Debré należał do kręgu jego najbliższych współpracowników i był członkiem założycielem Zgromadzenia Ludu Francuskiego. W czerwcu 1958 r., po powrocie de Gaulle'a do władzy, Debré objął w jego rządzie fotel ministra sprawiedliwości i był głównym konstruktorem prac nad projektem Konstytucji V Republiki. Jego przemówienie na forum Rady Stanu w sierpniu 1958 r. należy, obok wystapień samego de Gaulle'a, do najważniejszych dokumentów fundujących V Republikę ${ }^{2}$.

Wyjątkowość myśli Debré polegała na łączeniu silnej identyfikacji z tradycją republikańską z wolą gruntownej reformy demokracji parlamentarnej. W obozie Wolnej Francji i Résistance tendencja ta należała do zdecydowanej mniejszości. Wypada podkreślić, że de Gaulle ugruntował zasady republikańskie w sporze z Vichy o legitymację i legalizm władzy. Ponadto sprzeciw wobec autorytaryzmu Vichy wypowiedziany był na gruncie respektu dla zasad republikańskich i ustaw konstytucyjnych z 1875 r., co musiało ograniczać krytykę III Republiki. Większość środowisk Résistance i Wolnej Francji nie łączyła odnowy Francji z planem zmian instytucjonalnych, przypisując zasadnicze znacznie wymianie elit i odrodzeniu postaw obywatelskich.

Debré nie podzielał tych poglądów. Uważał, że wola polityczna i dobry obyczaj bez wsparcia ze strony dobrych instytucji nie są w stanie odbudować siły i znaczenia Francji. Punktem wyjścia jego koncepcji ustrojowych była surowa ocena ustroju III Republiki. W jego oczach praktyka ustrojowa lat 30. była wyrazem degeneracji ustroju III Republiki. W tekście Konstytucyjny problem Francji pisał:

Nie zdajemy sobie wystarczająco sprawy z tego, że upadek Francji w okresie ostatnich dziesięciu lat w dużej mierze jest efektem degeneracji ustroju z 1875 r. właśnie w postaci tego typu rządów. Prezydent Republiki nie był głową państwa. Senat stał się wyłącznie organem kontrolnym, którego wpływy stale zresztą malały. Izba Deputowanych, nie obawiając się rozwiązania, które wydawało się niemożliwe w związku z jej charakterem organu reprezentującego suwerenność narodu, przyznawała sobie władzę niczym nieograniczoną. Jej sesje były prawie nieprzerwane. Rząd był na jej rozkazy, odwoływany w przypadku najmniejszego konfliktu. Komisje stale kontrolowały działania ministrów. W ten sposób nasz ustrój stopniowo ewoluował, dochodząc do charakterystycznej dla rządów Zgromadzenia chaotycznej i przejściowej dyktatury opierającej się na delegowaniu pełni władzy w ręce rządu ${ }^{3}$.

${ }^{1}$ S. Aromatario, La pensée politique et constitutionnelle de Michel Debré, Paris 2006; a także P. Debré, R. Debré, [w:] Dictionnaire de Gaulle, red. C. Andrieu, P. Braud, G. Piketty, Paris 2006, s. 318-319.

2 Zob. K.M. Ujazdowski, Geneza i tożsamość Konstytucji V Republiki francuskiej, Kraków 2013, s. 147-149.

${ }^{3}$ M. Debré, Konstytucyjny problem Francji, [w:] K.M. Ujazdowski, V Republika Francuska. Idee, Konstytucja, Interpretacje, Kraków 2010, s. 149. W innej publikacji pisał, że „parlament 
W opinii Debré rządy zgromadzenia eliminowały możliwość prowadzenia długoterminowej polityki państwowej. W ich przypadku interes generalny ustępował partykularnym interesom różnych klas społecznych, a prawa i wolności były zagrożone przez Zgromadzenie, którego suwerenność nie zna granic ${ }^{4}$. We wspomnianej pracy podkreślał, że III Republika w rzeczywistości była pozbawiona szefa państwa:

We Francji ten niedobór szefa państwa jest dużo poważniejszy, niż się sądzi. Znosi on najskuteczniejszą przeszkodę nadużyć parlamentarnych. Rząd traci swoje pierwsze wsparcie: staje się po prostu zgromadzeniem komisarzy większości. Ustrój parlamentarny zmienia się w rządy konwencji: jedno zgromadzenie sprawuje władzę bez ograniczeń. Suwerenność jest zapewniona, ale poszanowanie wolności jest zaprzepaszczone ${ }^{5}$.

Michel Debré uważał, że jeśli powojenna Francja nie dokona zmian ustrojowych, doprowadzi to do restauracji rządów Zgromadzenia ze wszystkimi tego negatywnymi konsekwencjami. Autor Refaire la France definiował reformę jako budowę autentycznego parlamentaryzmu w opozycji do rządów zgromadzenia. Michel Debré stale posługiwał się tymi pojęciami, powtórzył je także w słynnym wystąpieniu przed Radą Stanu w sierpniu 1958 r. ${ }^{6}$

$\mathrm{W}$ pracach napisanych w okresie wojny przedstawił całą gamę nowych instytucji, które znalazły się w Konstytucji V Republiki. Bardzo istotne jest to, że już wtedy Debré zaprojektował przemyślaną i spójną wizję zracjonalizowanego parlamentaryzmu z intencją budowy stabilnych i efektywnych rządów parlamentarnych. Zracjonalizowany parlamentaryzm zaprojektowany przez Debré wiązał reformę prawa wyborczego z nowym urządzeniem (agencement) relacji między egzekutywą i legislatywą. Autor Refaire de la France był zdecydowanym rzecznikiem wyborów większościowych w jednej turze. „Gdy wybory stają się pojedynkiem dwóch sił, tworzą większość" - pisał w tekście Pour une reforme constitutionnelle $e^{7}$. Uważał, że wybory $\mathrm{w}$ dwóch turach $\mathrm{w}$ wersji stosowanej w III Republice (a więc z możliwością startu w drugiej turze wszystkich

francuski upadł i doprowadził Francję do upadku" (Jacquier-Bruère [pseud. M. Debré], E. Monick, Refaire la France: l'effort d'une génération, przeł. M. Miałkowska, Paris 1945, s. 146).

${ }^{4}$ Podobne myśli wyraził M. Debré w artykule Les problèmes constitutionnels: „Rząd stał się przedstawicielem parlamentu. Projekty ustaw i budżetu są poddawane dyskusji przez komisje, które zastępują ich propozycje swoimi. Jego odpowiedzialność przed Parlamentem jest bez przerwy poddawana refutacji tak, żeby nie mógł korzystać ze swoich teoretycznych praw nadawanych przez konstytucję. W samym wnętrzu służby publicznej, wpływ członka parlamentu góruje nad autorytetem ministra. Niestabilność rządowa, podstawowa zasada i tradycja Trzeciej Republiki, jest dowodem niezaprzeczalnej potęgi zdobytej przez Zgromadzenia" (idem, Les problèmes constitutionnels, [w:] idem, La République et ses problèmes, Paris 1952, s. 39).

5 Jacquier-Bruère, E. Monick, op. cit., s. 117-118.

6 M. Debré, Przemówienie przed Rada Stanu 27 sierpnia 1958 r., [w:] K.M. Ujazdowski, V Republika Francuska..., s. 229-245.

7 M. Debré, Pour une reforme constitutionnelle, [w:] idem, La République et ses problèmes..., s. 36 .

Studia nad Autorytaryzmem i Totalitaryzmem 38, nr 4, 2016

(C) for this edition by CNS 
kandydatów, a nawet kandydatów nowych, którzy nie startowali uprzednio) odraczają w czasie wyborczą rywalizację, nie wymuszają koalicji wyborczych i przynoszą skutek w postaci rozdrobnienia politycznego ${ }^{8}$.

Michel Debré chciał, by centrum władzy znajdowało się w rękach dysponującego większością parlamentarną rządu z premierem jako politycznym szefem państwa. Do niego miało należeć prawo do występowania z wnioskiem o rozwiązanie izb i uruchomienie arbitrażu narodu. Autor proponował:

Rządem kieruje premier wybierany przez głowę państwa w zależności od większości w parlamencie, wybranej przez wyborców. Premier jest politycznym szefem państwa. Ponosi odpowiedzialność za rząd. Jest kontrolowany przez parlament, lecz może, w określonej sytuacji, zwrócić się do narodu, kierując do głowy państwa wniosek o rozwiązanie zgromadzenia wybranego bezpośrednio przez naród ${ }^{9}$.

W tak zarysowanej wizji prezydent miał być „zwornikiem sklepienia” (clef de voûte) odnowionego ustroju parlamentarnego, opiekunem premiera, nie zaś aktywnym konstruktorem egzekutywy. W tej sferze zachodzić będzie poważna różnica między poglądami Debré a jego patronem de Gaulle'em, który lokował w prezydenturze ośrodek aktywnego przywództwa państwowego. Wedle Debré misja ustrojowa prezydenta miała polegać na dbaniu o dobro państwa w długiej perspektywie czasowej oraz na lojalnym wspieraniu rządu.

Można mówić o nawiązaniu przez Debré do wysuniętej przez Constanta koncepcji monarchii jako władzy neutralnej i moderującej. Constantowskie pochodzenie ma z pewnością pojęcie prezydenta jako „Zwornika sklepienia” systemu konstytucyjnego ${ }^{10}$. Propozycja zakładała wydłużenie kadencji prezydenta i zmianę charakteru jego mandatu. Prezydent miał być wybierany na długą (dwunastoletnią) kadencję, ale już bez prawa reelekcji ${ }^{11}$. Michel Debré proponował wybór prezydenta przez odrębne kolegium, które „obok członków parlamentu, gromadzi przedstawicieli rad generalnych i miejskich, być może przedstawicieli szkół wyższych, sądownictwa, związków zawodowych"12. Kombinacja obu instytucji miała przynieść pozytywny efekt ustrojowy w postaci upodmiotowienia prezydenta: „Kadencja 12-letnia, zapewnione dożywotnie wynagrodzenie bez prawa reelekcji, rozszerzony elektorat - to powinno wystarczyć, aby wyposażyć budowlę francuskich instytucji w zwornik, którego tak jej brakowało od 50 lat"13.

Kluczowym elementem projektu Debré było wyposażenie rządu parlamentarnego w zestaw instrumentów umożliwiających efektywne rządzenie. Przyszły architekt V Republiki przedstawił propozycję sesyjności parlamentu,

${ }^{8}$ Ibidem, s. 37.

${ }^{9}$ M. Debré, Konstytucyjny problem Francji..., s. 151.

10 Zob. W. Szyszkowski, Benjamin Constant. Doktryna polityczno-prawna na tle epoki, Warszawa1984, s. 89.

11 W projekcie CGE ostatecznie przyjęto kadencję 7-letnią.

12 M. Debré, Konstytucyjny problem Francji..., s. 153.

13 Ibidem. 
wprowadzenia sztywnego limitu liczby komisji stałych, konstytucjonalizacji debaty budżetowej, zakazu posługiwania się instytucją interpelacji w celu egzekwowania politycznej odpowiedzialności rządu przez parlament. Michel Debré uważał, że francuska elita parlamentarna nie zrezygnuje z własnych przyzwyczajeń i przywilejów. Dlatego też już w książce Refaire de la France postulował interwencję konstytucyjną w tej sferze i przekonywał, że instytucje te powinny mieć status norm konstytucyjnych.

Wypada także zwrócić uwagę na postulat określenia w konstytucji domeny ustawowej w kwestiach o fundamentalnym znaczeniu, tym samym na otwarcie szerszego pola dla prawodawstwa rządowego. Jeszcze przed wojną pojawiły się sugestie wyposażenia rządu w możliwość wydawania dekretów z mocą ustaw ${ }^{14}$. Debré szedł dalej i wysuwał propozycję systemową o podwójnym celu. Dawał rządowi możliwość efektywnego rządzenia w postaci samodzielnego prawodawstwa rządowego, a parlamentowi - zachowanie wyłączności w sferach podstawowych dla funkcjonowania wspólnoty politycznej. W tekście Konstytucyjny problem Francji pisał:

Normalne jest zatem ustalenie dla parlamentu, w treści konstytucji, po to, aby uniknąć utraty przez niego szacunku w oczach narodu, czy to z powodu nadmiernej aktywności, czy nadmiernej bierności, zakresu spraw zarezerwowanych dla niego, których nie może delegować. Do zakresu tego należą przede wszystkim prawa podstawowe jednostki — wolność jednostki, wolność prasy, wolność poglądów, stan cywilny jednostki — oraz najważniejsze problemy polityczne, organizacja władzy publicznej, umowy z innymi krajami. Należy natomiast pozostawić rządowi swobodę decydowania w sprawach wychodzących poza ten zasadniczy zakres ${ }^{15}$.

Wspominałem już, że Michel Debré był pomysłodawcą powołania Państwowej Szkoły Administracji (ENA). Był również gorącym zwolennikiem profesjonalizacji państwa, ścisłej współpracy rządu z Radą Stanu i odnowienia składu tej instytucji, tak aby „nie składała się ona... z prawników żyjących w oderwaniu od polityki i administracji" ${ }^{16}$. Michel Debré w istotnym zakresie przyczynił się ponadto do wprowadzenia w lipcu 1945 r. obligatoryjnego opiniowania rządowych projektów ustaw przez Radę Stanu. Jednak apogeum jego wpływów przypadło na rok 1958, gdy kierował pracami nad nową konstytucją. Wprawdzie konstytucja V Republiki, zgodnie z ideami samego de Gaulle'a, złożyła przywództwo w ręce prezydenta, a nie premiera, to Debré wprowadził do niej zaprojektowane w okresie Résistance instytucje racjonalizujące rządy parlamentarne. Dzięki nim francuski system konstytucyjny działa efektywnie w każdych warunkach, także w okresach cohabitation i w braku stabilnej większości rządowej. Podsumowując, należy stwierdzić, że Debré dał wyjątkową lekcję krytycznego myślenia o ustroju państwa — potrafił właściwie zdefiniować słabości rządów parlamentarnych i przeprowadzić ich skuteczną naprawę.

14 R. Capitant, Reforma parlamentaryzmu, [w:] K.M. Ujazdowski, V Republika Francuska..., s. $163-184$.

15 M. Debré, Konstytucyjny problem Francji..., s. 155.

16 Ibidem, s. 155-156. 


\section{Bibliografia}

Aromatario S., La pensée politique et constitutionnelle de Michel Debré, Paris 2006.

Capitant R., Reforma parlamentaryzmu, [w:] K.M. Ujazdowski, V Republika Francuska. Idee, Konstytucja, Interpretacje, Kraków 2010.

Debré M., Konstytucyjny problem Francji, [w:] K.M. Ujazdowski, V Republika Francuska. Idee, Konstytucja, Interpretacja, Kraków 2010.

Debré M., La République et ses problèmes, Paris 1952.

Debré M., Les problèmes constitutionnels, [w:] idem, La République et ses problèmes, Paris 1952.

Debré M., Pour une reforme constitutionnelle, [w:] idem, La République et ses problèmes, Paris 1952.

Debré M., Przemówienie przed Rada Stanu 27 sierpnia 1958 r., [w:] K.M. Ujazdowski, VRepublika Francuska. Idee, Konstytucja, Interpretacja, Kraków 2010.

Debré P., Debré R., [hasło w:] Dictionnaire de Gaulle, red. C. Andrieu, P. Braud, G. Piketty, Paris 2006.

Dictionnaire de Gaulle, red. C. Andrieu, P. Braud, G. Piketty, Paris 2006.

Jacquier-Bruère, Monick E., Refaire la France: l'effort d'une génération, przeł. M. Miałkowska, Paris 1945.

Szyszkowski W., Benjamin Constant. Doktryna polityczno-prawna na tle epoki, Warszawa 1984.

Ujazdowski K.M., V Republika Francuska. Idee, Konstytucja, Interpretacje, Kraków 2010.

Ujazdowski K.M., Geneza i tożsamość Konstytucji V Republiki francuskiej, Kraków 2013.

\section{EFFECTIVE PARLIAMENTARY DEMOCRACY BY MICHEL DEBRÉ}

\section{Summary}

In the 1930s, France epitomized a weakness of parliamentary democracy. Third Republic, that was recognized by many European countries as a model political system, was actually hit by a grave crisis combined with an increase of popularity of authoritarian trends. Undoubtedly, ineffectiveness of the French model of parliamentary democracy contributed to the fall of republican France in 1940. An in-depth and interesting analysis, which may also be recognized as an attempt made to overcome the weaknesses of parliamentary democracy, was put forward by Michel Debré in his writings published in the WWII years. One of the reasons why his draft of a rationalized parliamentary system deserves special attention is that this document inspired establishment of the Fifth Republic. Debré offered an exceptional lesson of critical thinking about the political system. This outstanding lawyer was able to correctly identify and effectively eliminate the vices of parliamentary governments.

Keywords: authoritarianism, Debré, effective democracy, constitutional reform, the Fifth Republic, rationalized parliamentary system.

Kazimierz Michał Ujazdowski

kmujazdowski@gmail.com 